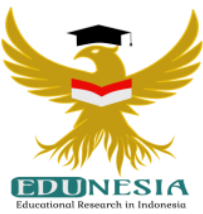

\title{
Blended Learning Assessment Instrument For Elementary School
}

\author{
Meta Yuliyana'; Rochmiyati²; Dina Maulina ${ }^{3}$ \\ 1,2,3 Department of Primary Education, Universitas Lampung, Indonesia \\ ${ }^{1}$ Corresponding Email: metayuliyana@gmail.com, Phone Number: 0896 xxxx xxxx
}

\author{
Article History: \\ Received: July 30, 2021 \\ Revised: August 12, 2021 \\ Accepted: August 24, 2021 \\ Online First: August 28, 2021
}

Keywords:

Blended Learning,

Assessment Instruments.

Kata Kunci:

Instrumen Penilaian,

Pembelajaran Campuran

\section{How to cite:}

Yuliyana, M., Rochmiyati, R., \& Maulina, D. (2021). Blended Learning Assessment Instrument For Elementary School. Edunesia: Jurnal Ilmiah Pendidikan, 2 (3): 668 676.

This is an open access article under the $C C-B Y-N C-N D$ license
Abstract: This article was written as the stage of designing a blended learning assessment instrument model in elementary schools. This study aims to identify an assessment model that accommodates the realm of cognitive learning. The design phase of this research is based on the ADDIE model framework. The research population is all students of class V SDN 1,2, and 3 Karanganyar, the research sample is class V students at SDN 2 Karanganyar who have implemented blended learning. The data analysis technique used in this research is the descriptive data analysis technique. Based on the author's hypothesis, the stages of the development model that can be used based on the results of the analysis of assessment instruments for blended learning, there are three types of assessment, namely selfassessment, peer assessment, and teacher assessment. This triangle model is expected to accommodate the realm of learning in the implementation of blended learning assessment.

Abstrak: Artikel ini ditulis sebagai tahap perancangan model instrumen penilaian blended learning di sekolah dasar. Penelitian ini bertujuan untuk mengidentifikasi model penilaian yang mengakomodasi ranah pembelajaran kognitif. Tahap desain penelitian ini didasarkan pada kerangka Model ADDIE, Populasi Penelitian adalah seluruh siswa kelas V SDN 1,2,dan 3 Karanganyar, Sampel penelitian adalah siswa kelas V SDN 2 Karanganyar yang telah menerapkan blended learning. Teknik analisis data yang digunakan dalam penelitian ini adalah teknik analisis data deskriptif. Berdasarkan hipotesis penulis maka tahapan model pengembangan yang dapat digunakan berdasarkan hasil analisis instrumen penilaian untuk blended learning, terdapat tiga jenis penilaian, yaitu penilaian diri, penilaian teman sejawat, dan penilaian Guru. Model segitiga ini diharapkan dapat mengakomodir ranah pembelajaran dalam pelaksanaan penilaian blended learning. 


\section{A. Introduction}

In this digital era, learning is no longer limited to space and time. Through the use of technology, teachers can develop more effective learning activities. One of these efforts is to use the internet for education, known as e-learning (Kemal \& Eddy, 2017). The benefits of the internet for education are that it can be an access to information sources, access to resource persons, and as a medium of cooperation. In addition, the use of internet facilities is not limited by space and time, so that the exchange of information and knowledge between students and educators can take place anywhere and anytime. (Alden-Rivers, 2019). Current research confirms (again) that computer technology can create an interactive and engaging (additional) learning environment that may have a positive effect on students' knowledge acquisition, skill acquisition, and perception. One form of using the internet for educational institutions is the model blended learning.

This model combines face-to-face (traditional) with learning-learning. In this way, the advantages of each method can be utilized optimally. Face-to-face meetings in class can be used to discuss the materials available in the system e-learning. This spurs students to be able to regulate the rhythm of learning not only in the classroom but also outside the classroom through the blended learning system (Mutaqin et al, 2016). Others use blended learning to reduce the face-to-face teaching component so that part-time students and those with family responsibilities have better access to learning. Given the variety of reasons for introducing mixed learning, what do we evaluate? Is it cost-effectiveness, practical benefits for specific groups of students, student attitudes or learning enhancement? (Ansie et al, 2005), In the evaluation stage, we provide an assessment of learning outcomes through student outcomes and recommend improvements in support of e-learning as well as collect feedback for continuous improvement in both courses. (Paturusi et al, 2012).

Current engagement models and instruments are inadequate due to contextual affordability (courses and levels of activity vs. institutions) and the amalgamation of engagement constructs and subconstructs. A new framework, applicable to engagement in general but also suitable for informing the creation of instruments to measure engagement in face-to-face and technology-mediated contexts, is needed to guide research in mixed learning settings (Lisa \& Charles, 2019), However, to improve mixed learning design requires understanding when students are involved with their learning and when they start to disengage. To do this, "engagement must be measured at the same level of specificity as the intervention" (Wang et al, 2014). Educators have long debated the merits of multiplechoice assessments over traditional "pencil-and-paper" assessments. It is often difficult for educators to decide which method is best suited for a given situation. Confusion between item types is even more acute in the online environment.

Students are rarely asked to provide long-typed answers on a computer in a formal exam setting. For the most part, it doesn't make sense to do so when there is a simpler and cheaper option available: handwriting exams in the exam room $\left(\mathrm{O}^{\prime}\right.$ Loughlin \& Steven, 2007). Another opinion from Graham et al (2019) More and more K-12 schools have adopted a mixed learning approach. Current empirical research is sparse on preparing teachers for mixed teaching, including the skills they must develop to teach in mixed contexts. This research focuses on these weaknesses, to systematically identify the skills needed to teach in a mixed learning context and develop and testing instruments that can be used to determine individual and whole school readiness for mixed teaching.

Based on the problems of previous researchers and the results of observations, interviews and filling out questionnaires at SDN 1,2, and 3 Karanganyar, Kec. Jatiagung, 
Kab. Lampung Selatan received information that teachers in class $\mathrm{V}$ had implemented blended learning, however, when applying the model blended learning, there were obstacles in assessing after blended learning was applied, from 6 teachers from 3 elementary schools, 5 of whom were still confused in assessing learning outcomes student. Because learning is carried out in a blend of face-to-face with online learning, the assessment carried out must also be by every activity that students do while participating in learning. The application of blended learning in providing assessment and evaluation is carried out through online and direct exams in class.

The Mid-Semester Examination is conducted in the classroom, namely by conducting the test in the classroom using the method open book, while the Final Semester Examination is conducted online using a google form which is sent directly to the teacher. The author feels dissatisfied with the assessment as it has been done because of the limitations of the instrument and instrument development guidelines for conducting the assessment. Ideally, the assessment is not only done through the Mid-Semester Examination and the Final Semester Examination but can be carried out throughout the learning process and every student activity can be assessed and evaluated.

For this reason, the author wants to formulate an appropriate assessment instrument model to use when conducting assessments blended learning that is applied so that innovative learning such as blended learning can guarantee the quality of learning, an appropriate assessment is needed. This research is expected to help teachers to be taken into consideration in developing an integrated thematic learning outcome assessment instrument for class $\mathrm{V}$ and also be used as reference material for teachers in developing learning outcomes assessment instruments that are adapted to the KI and KD used.

\section{B. Method}

The type of research conducted is Research and Development (R\&D) or development research. According to (Borg, \& Gall, 2003) "educational research and development (R\&D) is a process used to develop and validate educational products". According to Sugiyono (2012) development research aims to be able to produce certain products, including the process of testing validity, practicality, and effectiveness. The development model used in this study refers to the ADDIE development model. (Dick \& Carey, 2006) states that "ADDIE is an acronym referring to the major processes: Analysis, Design, Development, Implementation, and Evaluation". This model provides a dynamic and flexible guide tool in developing an effective curriculum, starting from analyzing the content to be developed, designing, developing products, namely the curriculum, implementing the curriculum and conducting evaluations.

This research was conducted in 3 elementary schools in 1 complex, namely SDN 1,2, and 3 Karanganyar, Kec. Jatiagung, Kab. Lampung Selatan. The research population was all fifth-grade students at SDN 1,2, and 3 Karanganyar, Kec. Jatiagung, Kab. Lampung Selatan. The research sample was the fifth-grade students of SDN 2 Karanganyar who had applied blended learning. The data collection methods in this study were assessment, observation, questionnaires and tests. While the data collection techniques with assessment formats, observation guides, questionnaires and question sheets. The data analysis technique used in this research is the descriptive data analysis technique. The analysis is described by describing the validity, practicality and effectiveness of using the instruments that have been developed. 


\section{Result and Discussion}

Results and discussion in this study provide a review of the definition of blended learning models of blended learning, assessment tools, assessment instruments blended learning, criteria model of evaluation instruments and instruments of assessment of learning outcomes blended learning in primary schools which include self-assessment, peer assessment and teacher assessment.

\section{a. Definition of Blended Learning}

Bersin (2004) defines blended learning as: "the combination of different training "media" (technologies, activities, and types of events) to create an optimum training program for a specific audience. The term "blended" means that traditional instructor-led training is being supplemented with other electronic formats. In the context of this book, blended learning programs use many different forms of learning, perhaps complemented with instructor-led training and other live formats". The blended learning model is a learning model that combines face-to-face teaching methods with computer-assisted teaching methods both offline and online to form an integrated learning approach. In the past, digital-based materials have been practised but within the limits of a supporting role, namely to support teaching face-to-face (Bonk \& Graham, 2004) Stated that the definition of blended learning generally includes:

a) The combination of instructional modalities or delivery media and technologies.

b) The combination of instructional methods, learning theories, and pedagogical dimensions.

c) The combination of online learning and face-to-face learning.

The combination of these various elements, both media and technology, theory, learning dimension strategies as well as face to face learning and online learning allows coverage of blended learning to a wider. So that teacher or learning designers can be creative in choosing the combination that best suits the conditions of students and the learning environment they face.

Blended learning aims to provide the most effective and efficient learning experience. (Zhu, 2016) states that blended learning can help students learn independently, improve critical thinking skills so that they realize the importance of lifelong learning. (Akarawang et al, 2016) explains that the use of the model blended learning can reach more students and has the advantage of schedule flexibility, which will increase student participation in learning.

Carman (2005) describes several things that need to be considered to be successful in implementing blended learning: a. Line event: synchronization between face-to-face learning and virtual learning at the same time and place directly in the same class/time in different places b. Self-paced learning: combining face-to-face learning and self-paced learning, both in the form of text-based and multimedia-based. Online (web, app, chatroom, youtube, etc) and offline (CD, print media, etc). c. Collaboration: building good collaboration between teachers and students in one school or between teachers and students 
from various other schools through communication tools built in the form of chatrooms, discussion forums, email, website/weblog, mobile phone, or WA, for deepening material, problem-solving or project assignments. d. Assessment: combining several types of assessments in the form of tests or non-tests, or authentic assessments in the form of projects or products that can be carried out either online or offline. e. Performance support materials: compiling learning digitally, both offline models (in the form of CDs, MP3, and DVDs) or online through the website).

Suhartono (2016) suggested guidelines for implementing blended learning in elementary schools for teachers, including; a. Prepare several learning videos, texts, photos, sounds, or images that match the curriculum content that has been downloaded from the internet, then saved on a flash disk or in a folder on the computer. Teachers can use these learning resources in face-to-face learning in class. The method taken by this teacher includes the implementation of blended learning but blended learning with an offline model. b. Develop learning materials and evaluation tasks (tests) by the curriculum content. This material can also be in the form of material downloaded from the internet, then stored in a CD room. The material on the CD is distributed to students to be studied and the assignments are studied and done at home with the help of parents. This is also learning with the "blended learning" model "offline". c. Utilize WA (Whatsapp), email groups, Facebook groups as learning media. In these media, the teacher can include initiation materials, discussion tasks, and tests for students to do at home with the help of parents, or to do with other friends from one school or several schools. This model also includes blended learning with hybrid or online models. d. Studying various materials on the internet by the material set out in the curriculum and using it as supplementary material in face-to-face learning in class.

\section{b. Assessment Instruments}

Through the evaluation can be known the effectiveness of the learning process and the level of achievement of the goals that have been set. Assessment of learning outcomes should meet in principle as expressed by Anderson (2003): significance (meaningfulness), anyone who is interested in the results of student assessments can see the meaning behind the assessment that has been done, (2) transparency or openness (explicitness), every party who needs information on student learning outcomes can find out how the teacher conducts student learning assessment activities and the results of the assessment. Transparency of information that is considered by teachers in determining student learning assessments, components of student learning assessments that makeup grades, data processing results of student learning assessment activities, etc., (3) fairness, every student has the same opportunity in the systematic assessment of learning by teachers and schools. Adil does not mean that every student acquires the same value but the gain value should be obtained by the learning abilities of each student, as well as meet the criterion of validity and reliability. 


\section{c. Instruments Assessment Blended Learning}

Assessment environment, blended learning, of course, includes assessments that are usually carried out in face-to-face meetings, then added with online learning assessments. Palloff \& Pratt (2009) write that it is necessary to consider the following principles for conducting online learning assessments, namely: 1) learner-centred assessment design includes self-reflection, 2) the design and scope of rubric levels for conducting assessments contribute to the discussion., assignments, projects and collaboration of all, 3) includes collaborative assessment through published working papers along with comments from other students, 4) encourages students to develop skills and provide feedback by providing guidelines on how to give good feedback, 5) use assessment techniques that are by the context and align them with learning objectives, 6) assessment designs must be clear, easy to understand and allow to be carried out in an online environment and 7) ask students' opinions as input on how to carry out the assessment should be done. The instrument for collecting data on learning outcomes given to students must have validity and reliability in measuring learning outcomes achieved by students. To ensure its validity and reliability, the research instrument should be tested first on other groups in the same population other than the research sample group.

\section{d. Criteria for the Instrument Evaluation Instrument Model}

Said to be valid, according to Nieven (1999), if the strategy reflects knowledge (content validity) and the product components must be consistent with each other (construct validity). Furthermore, an instrument is said to be practical if the instrument is used. Then an instrument is said to be effective if it gives results by the objectives set by the developer.

\section{e. Assessment Instruments for learning Outcomes Blended Learning}

The results of data collection show that most teachers at SDN 1, 2, and 3 do not yet have an optimal learning outcome assessment instrument so that in assessing student learning outcomes it is not optimal. Based on the author's hypothesis, the stages of the development model that can be used are as follows: The results of the analysis of assessment instruments for blended learning, there are three types of assessment, namely self-assessment, peer assessment, and teacher assessment. The following is an explanation of each type of assessment:

\section{Self-Assessment}

Self-assessment is the ability of students to follow, analyze, and judge their performance based on criteria and to determine how they can improve it. In conducting the assessment must take into account the abilities and experience needed to properly assess themselves. According to Brown (2005) self-assessment is a key process to help students 
reflect, understand, take action and take responsibility for the learning or activities they have done.

\section{Peer Assessment}

Peer assessment is an activity to give a decision on the work or study buddy. Peer assessment is a type of assessment that allows one student to assess another student in one lesson. assessment blended learning Effectiveall students become learners and educators. So, all learning participants are involved in providing input on the design, facilities, and direction of the learning process.

\section{Teacher Assessments}

Assessment of teachers so far has tended to be directed and limited to high-level summative assessment activities such as midterm and final exams. The teacher's role in blended learning is to provide ongoing and meaningful assessments to help students develop the necessary metacognitive skills and strategies to take responsibility for the learning they are engaged in.

The evaluation carried out in blended learning is carried out through two aspects, namely formative evaluation and summative evaluation. Formative evaluation is carried out at each learning step during the learning process. This evaluation is not only aimed at the level of temporary understanding of students but also evaluation of the learning process that has been carried out. Are there elements of learning that have not optimal performance, or are there things that hinder the learning process? All unwanted things found in the formative evaluation are then corrected and refined so that the next learning process can take place more optimally. Summative evaluation in blended learning is carried out to measure two aspects, namely aspects of students and aspects of the learning process. Summative evaluation of students is intended to find out how the level of understanding of students towards learning materials after the entire learning process is carried out. To find out, that is by collecting data on learning outcomes obtained from tests given to students after all learning materials are delivered.

The test used in the evaluation process is in the form of an essay question. This form of evaluation is very suitable for determining the students' high-level cognitive abilities (such as synthesis and analysis abilities). Summative evaluation is also intended to find out how the level of success of the previously designed learning process in realizing the achievement of the expected learning objectives. Many previous studies have shown that formative assessment can be used to improve student learning success (Black \& William, 2009), as an input for learning improvement depending on the results of the assessment. In addition to formative assessment, the summative assessment provides information after the learning process takes place.

This final assessment provides information on what students did or did not master, but it does not provide the information needed to improve learning or learning strategies while learning is taking place. This assessment is carried out at the end of the lesson, that is the reason the results do not help the teacher to change the learning that has taken place. As teachers transition to online learning and blended learning, which combine face-to-face activities in the classroom with computer-mediated activities, teachers need new ways to use today's best assessment tools. This environment creates several new possibilities for formative and summative assessments that allow teachers to quickly see meaningful student 
responses and tailor learning based on their needs. From the results of the needs analysis that the authors conducted, there is a need for techniques that provide a continuous assessment that can be used in the context of traditional learning, online learning, and blended learning.

\section{Conclusion}

Based on the results of the needs analysis conducted, it can be concluded that educators and students need assessment instruments for blended learning. From the aspect of supporting facilities, both those provided by the school and those owned by the students are adequate for the implementation of assessment instruments blended learning. This means that assessment instrument model blended learning in elementary schools is needed.

Based on these conclusions, the suggestion that the author proposes is that an instrument that will be developed based on a needs analysis can accommodate the realm of learning assessment and all learning activities, both traditional and virtual.

\section{References}

Akarawang, C., Kidrakran, P., \& Nuangchalerm, P. (2016). Developing ICT Competency for Thai Teachers through Blended Training. Online Submission, 10(1), 15-21.

Anderson, L. W. (2003). Classroom assessment: Enhancing the quality of teacher decision making. New Jersey: Lawrence Erlbaum Associates Inc.

Mutaqin, A., Marethi, I., \& Syamsuri, S. (2016). Model Blended Learning di Program Studi Pendidikan Matematika UNTIRTA. Cakrawala Pendidikan, (1), 86593.

Harding, A., Kaczynski, D., \& Wood, L. (2012, October). Evaluation of blended learning: analysis of qualitative data. In Proceedings of The Australian Conference on Science and Mathematics Education (Vol. 11).

Bersin, J. (2004). The Blended Beaming Book: Best Bractices, Proven Methodologies, and Lessons Learned. San Francisco: Pfeiffer.

Black, P., \& William, D. (2009). Developing the Theory of Formative Assessment. Educational Assessment, Evaluation and Accountability, 21, 5-31. https:// doi.org/10.1007/s11092-008-9068-5.

Bonk dan Graham. (2004). Handbook of Blended Learning: Global Perspective, Local Design (Cheicester: John Wiley \& Sons Inc, 2004), 48.

Brown, S. (2005). Assessment for learning. Learning and Teaching in Higher Education, 1(1), $81-89$ Retrieved from http://www2.glos.ac.uk/offload/tli/lets/lathe/issue1/articles/brown.pdf.

Carman, J. M. (2005, Agustus). Blended learning design: Five key ingredients. President Agilant Learning. 
Graham, C. R., Borup, J., Pulham, E., \& Larsen, R. (2019). K-12 blended teaching readiness: Model and instrument development. Journal of Research on Technology in Education, 51(3), 239-258.

Dick, W., Carey, L., \& Carey, J. O. (2006). The systematic design of instruction (4th Ed.). New York: Haper Collins College Publishers.

O'Loughlin, E., \& Osterlind, S. J. (2007). A Study of Blended Assessment Techniques in On-line Testing. AISHE Conference 2007 Teaching and Learning in the Changing World of Higher Education : NUI Maynooth, Ireland.

Gall, M. D., Borg, W. R., \& Gall, J. P. (2003). Educational research: An introduction . New York: Longman Group Publishing.

Kemal, I., \& Setyandi, E. (2017). The Effectivenes of Managerial Skills Of State Elementary School Principals in East Jakarta. Jurnal Ilmiah Peuradeun, 5 (2), pp. 157-168. https://doi.org/10.26811/ peuradeun.v5i2.133

Nieveen, N. (1999). Prototyping to Reach Product Quality. Dordrecht:Kluwer Academic Publisher.

Palloff, R. M., \& Pratt, K. (2009). Assesing the Online Learner. San Fransisco: John Wiley \& Sons, Inc.

Paturusi, S. D., Chisaki, Y., \& Usagawa, T. (2012). Development and Evaluation of the Blended LearningCourses at Sam Ratulangi University in Indonesia. International Journal of e-Education, e-Business, e-Management and e-Learning, 2(3), 242.

Sugiyono. (2012). Metode penelitian kuantitatif kualitatif dan RED. Bandung: Alfabeta.

Suhartono. (2016). Menggagas pendekatan blended learning di sekolah dasar. Prosiding Temu Ilmiah Nasional Guru (TING) VIII.

Wang, Z., Bergin, C., \& Bergin, D. A. (2014). Measuring engagement in fourth to twelfth grade classrooms: The Classroom Engagement Inventory. School Psychology Quarterly, 29(4), 517-535. https:// doi.org/10.1037/spq0000050

Zhu, N. (2016). Developing a blended type course of introduction to hybrid vehicles. Journal of Education and Learning. 10 (1): 1-7. 